AperTO - Archivio Istituzionale Open Access dell'Università di Torino

\title{
Cosmopolitanism. The Mediterranean Archives
}

\section{This is the author's manuscript}

Original Citation:

Availability:

This version is available http://hdl.handle.net/2318/106692

since

Terms of use:

Open Access

Anyone can freely access the full text of works made available as "Open Access". Works made available under a Creative Commons license can be used according to the terms and conditions of said license. Use of all other works requires consent of the right holder (author or publisher) if not exempted from copyright protection by the applicable law. 


\section{(6) \\ UNIVERSITÀ DEGLI STUDI DI TORINO}

This is an author version of the contribution published on:

Questa è la versione dell'autore dell'opera:

GEOGRAPHICAL REVIEW, Volume 102, Issue 3, July 2012,

10.1111/j.1931-0846.2012.00153.x

The definitive version is available at:

La versione definitiva è disponibile alla URL:

http://onlinelibrary.wiley.com/doi/10.1111/j.1931-0846.2012.00153.x/abstract 


\section{Cosmopolitanism: The Mediterranean Archives}

Paolo Giaccaria

There can be no doubt that cosmopolitanism is now a key concept, not only traveling across the disciplinary boundaries of the social sciences but also those between academic knowledge and popular imagination. As Calhoun claims, "[c]osmopolitanism is in fashion. The trend started in the 1990s, after the end of the cold war and amid intensifying globalization. Cosmopolitan is now a compliment for the suave in a way it hadn't been since the 1920s or at least the 1960s, when in cold war spirit spies epitomized the cosmopolitan" $(2008,106)$. Cosmopolitanism today sits firmly in the agenda of the social sciences (Beck 2006), emancipatory politics (Pieterse, 2006), the United Nations (Taylor 1999), and the European Union (Rumford 2007). Despite being fiercely contested (Beck 2002), a "cosmopolitanism turn" (Delanty 2009, 3) is central to many of the key issues and debates concerning contemporary modernity (Toulmin 1992). Present-day cosmopolitanism is particularly associated with globalization (Beck and Sznaider 2006; Delanty 2006; Held 2010) and its different themes and interpretations: human rights and democratization (Archibugi 2006; Cheah 2006), multiculturalism (Rundell 2004; Parekh 2006), diasporas and migration (Werbner 1999), elite mobility (Calhoun 2002), ethics (Appiah 2007), and citizenship (Benhabib 2006).

Within this broad and growing literature, the purpose of this article is to discuss cosmopolitanism from a geographical perspective - and more specifically from a Mediterranean perspective. As David Harvey claims, geographical knowledge should be assumed as a "condition of possibility" for any foundation of cosmopolitanism, from Kant to Nussbaum and beyond (2009, 11, 29-31). He is even more justified in asking "what kind of geographical knowledge is adequate to what kind of cosmopolitan ethic? Failure to answer that deeper question condemns cosmopolitanism of any sort to remain an abstracted discourse with no tangible meaning other than the ad hoc, pragmatic, and often opportunistic application of universal principles to particular geographical instances" ( Harvey 2000, 547).

From this perspective the rather marginal interest that cosmopolitanism - in particular in its philosophical and political declination - has aroused amid geographers is quite surprising, as Schueth and O'Loughlin acknowledge $(2008,926)$. Even Harvey's seminal article in Public Culture in 2000 did not succeed in sparking debate on cosmopolitanism among geographers (Harvey 2000). To my knowledge, only Cosgrove (2003) and Gidwani (2006) - and, to some extent, Mitchell (2007) - directly engage with Harvey's claim that "disruptive spatiality worms its way into critical examination of cosmopolitanism" (Harvey 2000, 540). Similarly, in David Harvey: A Critical Reader, edited in 2006 by Noel Castree and Derek Gregory, little or no attention is paid to Harvey's reflection on Kant and cosmopolitanism. On the contrary, most of the recent, yet occasional, geographical reflection on philosophical and political cosmopolitanism (Latham 2002; Popke 2007; Schueth and O'Loughlin 2008) seems more at ease with Massey's idea of "a global sense of place" (1994, 146-156) than with Harvey's all-encompassing structuralist space/time framework (2009, 145-148). ${ }^{\text {' }}$

I believe that "geographic knowledge" can contribute to address two fundamental issues which lie unresolved at the very heart of the cosmopolitan debate. The first one is the focus almost exclusive on present-day cosmopolitanism and/or on the Eurocentric tradition directly linking Greek and Latin Stoicism to contemporary liberal cosmopolitanism à la Nussbaum via the Enlightenment and Kant's "perpetual peace." As a consequence, little or no attention is paid to alternative genealogies of cosmopolitanism, rooted in different traditions, situated in a variety of spaces and times, that only the reading of the "new archives, geographies, and practices of different historical Cosmopolitanisms" (Pollock et al. 2000, 587) can 
unveil. The second issue is that most of the cosmopolitanism literature privileges either the cosmos (the universal) or the polis (the particular), missing the oxymoronic link that connects them in a "field of tensions" (Delanty 2006) and falling into a sort of a dichotomic trap. In this context, I believe that geography can contribute to grasp the Janus ambiguity and Protean complexity of cosmopolitanism. Cosmopolitanism is not simply about either being a "citizen of the world" or bringing the world into the city. In my understanding, the essence of cosmopolitanism cannot be grasped without also understanding this inherent tension between the universal and the particular "constituting the basic animus of cosmopolitanism" (Delanty 2006: 35).

In this paper, I address how this tension (between Eurocentric cosmopolitanism and other cosmopolitan traditions, as well as between cosmos and polis) may be made sensible from a post-colonial and Mediterranean perspective. Why the Mediterranean? Because the Mediterranean can be interpreted as a space where something relevant happened in relation to the making of cosmopolitan ideals and practices, a space where, at different times, differently nuanced cosmopolitanisms confronted, overlapped, and blurred into each other, and where cosmos and polis express an oxymoric tension between universalism and particularism. The Mediterranean itself is trapped into a tension between opposite interpretations (Giaccaria and Minca 2011). On the one hand, it is marginalized as a residual space, isolated from the great processes of modernity and modernization. Such a marginalization, as we shall see, is evident even in the postcolonial understanding of the North-South imperial and colonial relationship. On the other hand, it is sometimes assumed as a "paradigm" for searching and investigating alternative modernities, as a space where different genealogies of modernity can be traced and reinterpreted (Chambers 2008; Matvejevic 1999). This tension is particularly evident in allegedly cosmopolitan cities, where the cosmopolitan past is reworked in the search for new forms of hospitality, conviviality, and resistance (Leontidou 2010; Söderström 2009), but also in order to brand a neo-liberal understanding of the city, translating memory and nostalgia into "easy faces of cosmopolitanism" (Calhoun 2002, 889), in order to attract frequent-flier elites and international investors (Della Dora 2006; Mills 2010).

In order to elaborate on these concerns the paper will be broken down in to four sections. In the first one, the focus is on postcolonial critical cosmopolitanism, in particular on Mignolo's reflections linking his "border thinking" theory (2000b) to the understanding of the complex relationship between cosmopolitanism and coloniality (2000a; 2010; see also Kramsch 2007 and Mitchell 2007). In the second part I claim that a Mediterranean perspective can help to highlight some key features of the postcolonial critical reading of cosmopolitanism. In the third section, drawing on Engin Isin (2002), I attempt to outline a cosmopolitan reading of the tension between empire and city which connotes Mediterranean imperial and colonial cosmopolitanism. Finally, the fourth section will deal with the Ottoman millet system, considered as a peculiar dispositif influencing both the making and the unmaking of cosmopolitanism in Mediterranean port cities. I will conclude by posing the question: "What can we learn from cosmopolitanism(s) in the Mediterranean?"

\section{Postcolonial Archives and Geographies: Relocating Cosmopolitanism}

According to Pollock and his fellow editors of the special issue on cosmopolitanism published in Public Culture in 2000, a postcolonial approach to cosmopolitanism is

interested to see what new archives might be brought to bear on the analysis of cosmopolitanism; to discover whether the historical and, what is equally important, the geocultural perspective on the problem 
could be extended beyond the singular, privileged location of European thought and history; and to determine whether disciplinary approaches could be varied so as to move the discussion beyond the stultifying preoccupations of Western philosophy and to allow the possibility of capturing the wider range of cosmopolitan practices that have actually existed in history. For it is only through such proceduresadducing new empirical data on the variety of cosmopolitanisms and the new problematics that accompany them, decentering the conventional locus, and investigating from a wide range of scholarly perspectivesthat new and post-universalist cosmopolitanisms ... have the potential to come into being. ... What the new archives, geographies, and practices of different historical cosmopolitanisms might reveal is precisely a cultural illogic for modernity that makes perfectly good non-modern sense. They might help us see that cosmopolitanism is not a circle created by culture diffused from a center, but instead, that centers are everywhere and circumferences nowhere. (Pollock et al. 2000, 585, 587-8, emphasis added)

In particular, within postcolonial narratives of cosmopolitanism, I believe that Mignolo's application of what he calls the "colonial difference" and "border thinking" (2000b) to cosmopolitanism (2000a; 2010) is particularly useful for the task of the present article. If the colonial difference "is the space in which global design have to be adapted, adopted, rejected, integrated, or ignored" (2000b, ix) then border thinking "is more than a hybrid enunciation. It is a fractured enunciation in dialogic situations with the territorial and hegemonic cosmology" ( $\mathrm{x}$ ). In particular, Mignolo's work relates cosmopolitanism, modernity, and coloniality, and outlines a historical genealogy that connects different moments in the making of modernity/coloniality.

Fundamental to my argument here is that Mignolo challenges the mainstream "family tree" of contemporary philosophical cosmopolitanism, which directly links Kant to Zeno, Cicero and the ancient Stoics, highlighting a spatial and temporal 'void' in-between (Nussbaum 1997; Delanty 2009, 20-41; for a critique, see: Pagden 2000). Mignolo fills this void with historical and spatial content: a specific time (the sixteenth century) and a specific space (Mediterranean Spain) become a fundamental "locus of enunciation" of the cosmopolitan/modern/colonial discourse (2000a, 728-730). Moreover, Walter Mignolo traces the marginalization of the Mediterranean/Spanish genealogy of cosmopolitanism back to the Enlightenment thinkers and signally to Kant's Anthropology from a Pragmatic Point of View, where the German philosopher describes a hierarchy of six European nations, classified according to the "character of the nation" and to the "character of the blood" in two groups: the first one comprises the growing colonial powers of France, England and Germany; the second encompasses a decaying Portugal, Spain and Italy. A sort of a "spatial garbage-can" finally includes Russia, Poland, Turkey and Greece, the margins of modern enlightened Europe." Through "the invention of the South of Europe [...] Kant's cosmopolitanism was cast under the implicit assumptions that beyond the heart of Europe was the land of those who had to be brought into civilization and, in the South of Europe, the Latin and Catholic countries, some of them - like Spain and Portugal - too close to the Moors and with mixed blood (Mignolo 2010, 123).

What Mignolo points out here is that the 'scientific' - and colonial - invention of the Mediterranean (Bourguet et al. 1998), its simultaneous description and colonization as a space of (subaltern) alterity with respect to the core of European modernity. Challenging this Kantian and Hegelian geographical imagination, he brings the sixteenth and seventeenth-century Mediterranean back to the foreground of the cosmopolitanism/modernity/colonialism trilogy, as a fundamental space where both global designs and cosmopolitan projects are considered, disputed and shaped (Mignolo 2000a, 731).

\section{Rethinking Cosmopolitan Spatiality from the Mediterranean}


Despite its relevance to our argument, Mignolo's account shows some blind spots that should be addressed here. While drawing on Janet Abu-Lughod's (1991) largely Mediterranean-centric reading of the world order between 1250 and 1350 A.D. and recognizing the Mediterranean's central role in the making of cosmopolitanism/modernity/colonialism (Mignolo 2000b, 26-29), Mignolo de facto abandons the Mediterranean to its own decline, almost sympathetically with Braudel's classic vulgate on the waning of Mediterranean centrality after the death of Philip II (1972).

But there is a "but." History did not cease in the Mediterranean after its marginalization and it was extraneous neither to cosmopolitanism nor to modernity. Maintaining the centrality that Mignolo ascribes to 1492 as a turning-point, the fact that the Moors and the Jews evicted from Spain and subsequently from Portugal did not melt into air cannot be ignored. Some Jews and conversos moved to the New World, where they suffered further persecution, but others traveled to Europe, where they made a fundamental contribution to the making of modernity (Yovel 2009) and others moved to the large domains of the Ottoman Empire, where they enjoyed protection and tolerance under the rule of the millet system ${ }^{i i i}$ (Levy 2002; Ben Naeh 2008). As lain Chambers claims, "at the one hand of the Mediterranean, the Arabs, the Jews, and the Rom were expelled from Europe; at the other, with the conquest of Constantinople and the Balkans by the Ottoman Turks, both Muslims and Jews returned to become once again internal, integral, to its history" $(2008,9)$. Judeo-Spanish magazines and newspapers flourished in Ottoman cities until the end of the Empire and beyond, blurring and melting European, Jewish and Ottoman culture in an original fashion (Stein 2000). Moreover, the Jewish presence played a specific role in the making of a Mediterranean urban cosmopolitanism which is still alive in the poetics and politics of memory and nostalgia. Salonica, Smyrna, Istanbul, Alexandria, Sarajevo, and Trieste are sites in a constellation of cities, where some of the features now commonly attributed to cultural cosmopolitanism (multiculturalism, transculturation, conviviality, diasporic mobility, hybridity, etc.) have been forged in the interplay between different communities and culture.

Moreover, in theorizing the relationship between coloniality, subaltern knowledge and border thinking, Mignolo describes the need to understand the making of the modern/colonial world-system in terms of both his interior and exterior borders $(2000,11)$, where the interior borders are related to the conflicts between empires and the exterior ones make reference to the conflicts between (hegemonic and subaltern, colonizer, and colonized) cosmologies. In my view, Mignolo's framework can be usefully applied to understanding the tension between cosmos and polis in the Mediterranean, albeit with some caveats. In many ways, in fact, the Mediterranean case seems more complex than the exemplary Latin-American evidence which Mignolo draws on. Interior borders, in the Mediterranean, are continuously reworked from the sixteenth until the twentieth century, mainly because of the permanence of "local" imperial powers within the Mediterranean space, most significantly the Habsburg Empire and the Ottoman Empire, but also, indirectly, the Spanish monarchy with the Bourbons' Kingdom of the Two Sicilies. Despite rivalry over the centuries, their coexistence actually worked as a "conditions of possibility" for cosmopolitanism in the Mediterranean, nurturing some degree of multiculturalism and multinationalism, which transcended the political and military clash between the two principle empires, Habsburg and Ottoman (Solnon 2009). The situation further changed in the early nineteenth century, when the French, British, and Russian imperial powers entered the Mediterranean game, multiplying the conflict and making the interior borders more and more complex: from Napoleon's military and scientific expedition to Egypt in 1798 to the fall of both the Habsburg and the Ottoman empires, in 1918 and 1922 respectively, five empires confronted each other in the Mediterranean. ${ }^{\text {iv }}$ This was not without consequences for the fortune of cosmopolitanism. On the one hand, the French and British colonial domination of vast areas enhanced a new age of trade and commercial diasporas in the area, mainly in the cities, reinforcing the making of an Orientalist cosmopolitan 
imagination about Mediterranean cities, finding its zenith in Lawrence Durrell's Alexandrian Quartet. On the other hand, the intervention of French, British and Russian empires and the slow decline of the Habsburg and Ottoman empires opened up to the emergence of vernacularism and nationalism in the Mediterranean, which established a further field of tensions in its urban cosmopolitanism.

Here it is important to address the second question that Mignolo raises, that of the exterior borders, that is, the issue of coloniality and colonialism, a question which is of course strictly related to the interior borders shaped by French and British imperialism in the Mediterranean. There is no doubt that the Mediterranean must be read as a "postcolonial sea" (Chambers 2008, 23-49) and that its colonial experience is strictly immanent to the making of a Mediterranean cosmopolitan imagination. Setting boundaries between a "European Self" and a "Mediterranean Other" was of course a key task in the making of the Mediterranean as a colonial space. It is also true that Orientalism played a key role from Napoleon's expedition onward and that cosmopolitan imagination about the Mediterranean was part of a broader Mediterraneanist discourse (Herzfeld, 1984; 2005). In this discourse Mediterranean cosmopolitanism is "elitist in formulation and content, it is laced with grief, and it privileges formal labels over content" (Hanley 2008, 1348; see also Driessen 2005).

The relationship between colonized and colonizers, between subaltern and hegemonic cultures, is nevertheless much more complex than it might appear from a classic postcolonial standpoint (Giaccaria and Minca 2011). European colonialism in the Mediterranean cannot be imagined without making reference to the search for modern Europe's roots in ancient Greece and to the fact that this quest actually took place as both a cause and a consequence of modernity/colonialism (Saïd 2005; Guthenke 2008). The production of the European South envisaged by Mignolo was always trapped between the establishment of a civilized distance between Northern Europeans and "corrupted" Mediterraneans (Horden and Purcell 2000) and the recognition of a cultural continuity between European modernity/coloniality and its Mediterranean past. This process was of course Orientalist and colonial, in that it aimed to establish a cultural alterity and consequently political, economic and social dominion, but it was also constantly disturbed by the need to make sense of European modernity's Mediterranean roots.

Of course, I am not claiming either that the Habsburg and Ottoman empires were empires "with a human face" - Mediterranean cosmopolitan port cities were not exempt from ethnic violence (Moore 2001) and they were important centers in the slavery trade (Zilfi 2010) - nor that French and British colonialism was 'less colonial' in the Mediterranean than elsewhere. My point is rather that Mediterranean cosmopolitanism cannot be reduced to an Orientalist discourse aimed at celebrating European-born cosmopolitan colonialists, as Hanley (2008) and Driessen (2005) seem to suggest. Its roots are not only in colonial cosmopolitanism but also, and more importantly, in a constellation of cosmopolitan moments which span Greek and Latin cosmopolitanism and Medieval cosmographies ${ }^{v}$ to modern/colonial cosmopolitanism, passing through the resilience of cosmopolitan institutions and practices of the Habsburg and Ottoman empires. Moreover, as Roger Owen has argued in his path-breaking The Middle East in the World Economy, 1800-1914 (Owen 1993), inter-imperial economic relationships were far from being a unidirectional, flat, colonial, and Orientalist domination.

In order to make sense of this Mediterranean complexity and ambiguity, I suggest that at least two cosmopolitan moments in the Mediterranean can be identified: an imperial cosmopolitanism and a colonial cosmopolitanism (see also Escallier 2003). Such a distinction is central here, as most of the literature on Mediterranean cosmopolitanism, from both of its advocates (Zubaida 2002) and critics (Driessen 2006; Hanley 2008), focuses almost exclusively on the colonial moment. Cosmopolitanism is interpreted in this 
view as the outcome of the encounter with the West and of colonial domination, consequently downplaying the role of previous cosmopolitan moments. Further, Paul Waley, albeit from a different perspective, praises for the multiplicity of cosmopolitanisms in the Mediterranean, claiming that Trieste was a space where two different cosmopolitanisms, Oriental and European, met and combined $(2009,253)$. Yet, I prefer to speak diachronically about two moments, rather than synchronically about two spaces of cosmopolitanism (Oriental and European). I will argue that East and West are inadequate categories in order to grasp cosmopolitanism(s) in the Mediterranean. At the same time, following Driessen (2005), I prefer to make reference to Mediterranean rather than to Middle Eastern cosmopolitan cities (Zubaida 2002; Hanley 2008), to the extent to which both the imperial and the colonial cosmopolitan ideals and practices cut across rigid geographical boundaries. Are eighteenth century Sarajevo and Salonika European? Are early twentieth century Alexandria and Istanbul Oriental/Middle Eastern? Does a model of the Islamic city exist and how is it differentiated in its Ottoman, Arab, European, and Anatolian versions? Such questions are unanswerable and, from the present paper's perspective, quite marginal.

Of course not all of the allegedly cosmopolitan Mediterranean cities have passed through these two moments in the same way and with the same intensity. Trieste, of course, has never been a colonial city in a proper sense and was established as a major imperial port-city only from the end of eighteenth century (Purvis 2009, 302), yet it established some sort of continuity with the Venetian dominion of the Adriatic, for instance through the adoption of "colonial Venetian" as a lingua franca (Minca 2009b). Salonika got its cosmopolitan "aura" already in the sixteenth century, a few decades after its Ottoman conquest, hosting thousands of Sephardic Jews evicted from Spain and Portugal and maintained such cosmopolitan character even after Greek independence, till the Nazi deportations to Auschwitz in the 1940s (Mazower 2004). Sarajevo has been passed through an even longer history of cosmopolitanism, belonging to two empires, the Ottoman one first and from 1878 onward to the Habsburg Empire, until the last dramatic siege in the nineties (Donia 2006). If it is true that Alexandria at the beginning of the nineteenth century was just "a small fishing settlement with around 5.000 inhabitants" (Fahmy 2006a, 263), it is also true that Alexandria's cosmopolitanism, with several breaks and interruption, dates back its Alexandrine foundation (Hirst and Silk 2006). Similar stories might be narrated of many other cities in the Mediterranean, from Cairo to Palermo, from Smyrna/Izmir to Aleppo, from Beirut to Constantinople/Istanbul. Despite their differences, all these cities share a common point: they are traditionally associated to cosmopolitanism - often in an elitist and nostalgic view, it must be acknowledged - but their history cannot be reduced to a tale of colonial dominion and Orientalist representation.

The interior and exterior borders of Mediterranean cosmopolitanism(s) are hence more complex and ambiguous than both cosmopolitan revival and postcolonial critique suggest. What Eldem, Goffman, and Masters notice about Aleppo, Izmir, and Istanbul can be applied to other Mediterranean imperial cities as well: "Aleppo, Izmir and Istanbul each in its own way constituted a borderland, whether between ethnicities ... between civilizations ... or between periods" (1999, 14, emphasis added). Hence, Mediterranean cosmopolitanism is neither about a golden age of imperial peace, tolerance and conviviality nor simply about the exciting lifestyle of bon vivant colonizers. It is rather to be read as an attempt to sustain a field of tensions between cosmos and polis, between general and particular, that took place during the five-century period which has been largely ignored by both Euro-centric and postcolonial cosmopolitans. Here I use the term "sustain" in the multifaceted sense of enduring, maintaining and nourishing. Such a tension must be endured to the extent that it can produce contradictions and conflicts, even urbicide as I will later show, maintained so that neither the cosmos nor the polis prevails over the other, and nourished as it is the very condition of possibility for Mediterranean cosmopolitanism. 


\section{Being Cosmopolitical in the Mediterranean: Cities beyond Fissiparousness}

Commenting on pre-modern cosmopolitan, Craig Calhoun argues the key issue in the very notion of cosmopolitanism, as he acknowledges that "[c]osmopolitanism has been a project of empires, of long distance trade and of cities," claiming at the same time that "[ $t$ ] he tolerance of diversity in great imperial and trading cities has always reflected, among other things, precisely the absence of need or opportunity to organize political self-rule" $(2002,871-872)$. In his synthetic, and to some extent reductive, description of the essence of cosmopolitanism - which brings together Stoicism, Christianity, and various pre-modern imperialisms - Calhoun engages explicitly with the spatial oxymoron which is constitutive of the very notion of cosmopolitanism. Cosmopolitanism bridges the cosmos and the polis, which in our Mediterranean context can be understood to stand for the empire and the city. More precisely he interprets this immanent tension in terms of how the political and hence citizenship is constructed in a cosmopolitan context.

Cosmopolitanism embodies, in fact, the tension between the empire and the city in negotiating and making decisions about citizenship, as it is already clear in its Stoic foundation ${ }^{\text {vi }}$ (Pagden 2000,6).

Reading cosmopolitanism as a field of tension between universal and particular, cosmos and polis, empire and city brings to the forefront the issue of power and citizenship, yet in a controversial fashion. On the one hand, Calhoun claims that "cosmopolitanism needs an account of how social solidarity and public discourse might develop enough in these wider networks to become the basis for active citizenship" $(2002,878)$, bringing together different genealogies of loyalty, belonging and solidarity and overcoming the universal versus particular divide. On the other hand, he suggests that "the absence of need or opportunity to organize political self-rule" acts as a sort condition of possibility for pre-modern, pre-colonial imperial, cosmopolitanism. He suggests that urban elites could afford to be cosmopolitan because they did not have to struggle for self-rule, as it was left to the imperial or colonial bureaucracy to make decisions for them. In this way, he seems to deny any relevance of "ancient" cosmopolitanisms for the current debate on cosmopolitanism. In his words: "The current pursuit of cosmopolitan democracy flies in the face of a long history in which cosmopolitan sensibilities thrived in market cities, imperial capitals, and court society while democracy was tied to the nation state. Cosmopolitanism flourished in Ottoman Istanbul and old-regime Paris partly because in neither were members of different cultures and communities invited to organize government together" $(2002,892)$.

\section{Weber's Fissiparousness Reconsidered}

When applied to the case of the Mediterranean, Calhoun's perspective sounds largely tributary to Orientalism, particularly to Max Weber's synoecistic account of the difference between Occidental and Oriental cities. As Engin Isin reminds us (2002, 7-22; see also Eldem et al. 1999, 1-16), Weber saw the Western cities as the locus where citizenship was established as the outcome of a process of unification and homogenization of city dwellers in terms of brotherhood, corporatism and self-rule. In Weber's account, the European bourgeoisie invented citizenship by first equipping itself for war and subsequently for self-rule whilst Oriental city dwellers rest trapped into sectarism and self-segregation, with little or no interest for self-rule. Weber's Orientalism fails to offer us a proper framework for understanding cosmopolitanism in the Mediterranean as it maintains that unity and homogeneity are fundamental features in defining clear boundaries of identity, belonging and hence citizenship. In Weber's synoecistic Orientalism, in fact, Islamic (and by extension Mediterranean) cities have been described as eminently 
fissiparous in that "these cities were divided into quarters or districts and each district had its homogeneous community and markets" (Isin 2002, 14). Fissiparousness is hence assumed as the main force contrasting the formulation of a modern account of citizenship as self-rule.

Such an emphasis on the fissiparousness of Islamic/Mediterranean cities is not only exaggerated and inaccurate (Eldem et al. 1999), but it would also undermine the very possibility of a Mediterranean cosmopolitanism outside the colonial framework of Western influence and domination. Only the acceptance of the "fissiparousness prejudice" can justify Zubaida's claim that it is not proper to speak about cosmopolitanism in the Middle East before the 'European impact':

The Ottoman Empire included many people and lands, for the most part organized in self-regulating communities, guilds, military units ... and groupings of scholars, scribes and functionaries. While there was a fair degree of social mobility, these were occupational rather than across communal lines ... This mobility, however, was into well-defined and bonded groupings ... with their distinctive discourses, practices and loyalties ... Until the nineteenth century, any small pocket of what might be seen as cosmopolitan milieux must have been confined to the higher echelons of Istanbul society (and maybe to some other centres in the Empire, such as Salonika). It was the 'European impact' (a euphemism for conquest and militaryeconomic dominance) that made its effect felt in particular corners of Ottoman societies in the Nineteenth century. $(2002,33)$

In other words, by accepting the "fissiparousness prejudice," Zubaida misses the complex bonds and interrelations that tie what, in the previous section, I have called "imperial cosmopolitanism" and "colonial cosmopolitanism." In a way, Weber, Zubaida, and Calhoun all misjudge Mediterranean cosmopolitan cities: cosmopolitanism occurred not despite but because of the strict bonds linking fissiparousness and self-rule.

\section{The Cosmopolitan City as a Difference Machine}

Mediterranean cosmopolitanism can be grasped only when abandoning the mythology of synoecism, of the urban unity and homogeneity producing citizenship. In doing so the city can be more fruitfully interpreted as a "difference machine" as in Isin's account:

The city is a difference machine insofar as it is understood as the configuration that is constituted by the dialogical encounter of groups formed and generated immanently in the process of taking up positions, orienting themselves for and against each other, inventing and assembling strategies and technologies, mobilizing various forms of capital, and making claims to that space that is objectified as "the city". Neither groups nor their identities exist before the encounter with the city. (Isin 2002, 49)

Consistent with Isin's account, cosmopolitanism can be understood as a way to master the city as a difference machine, where "cosmopolitan citizenship" emerges as the competence of sustaining the tension between the cosmos and the polis, between imperial citizenship and communitarian (and later national) citizenship, without producing any transcendental synthesis, characterized by unity and homogeneity. From this standpoint, Mediterranean cosmopolitanism is dramatic rather than dialectical. As Karahasan writes about Sarajevo during the 1990s siege: 
The Bosnian cultural system - established in its purest possible form exactly in Sarajevo- could be quite precisely defined as 'dramatic', as opposed to systems that could be described as 'dialectical'. ... Namely, the fundamental relationship between elements of the system is the oppositional tension, which means that its elements are posed against one another, and mutually bound by that opposition, wherein they define each other. ... The fundamental property of this kind of cultural system is pluralism, which is what makes it directly contrary to monistic cultural systems, which can be defined as dialectical. (1994, 5-6)

From this perspective it becomes possible to address a question that is essential for my understanding of Mediterranean cosmopolitanism and of its relationship with modernity; that is the link between self-rule, fissiparousness and cosmopolitanism. Khaled Fahmy has exemplary outlined this complex and ambiguous, aporia-like, relationship with reference to Alexandria, claiming that

[t]he explanatory power of the discourse of cosmopolitanism is undermined by its simultaneous adoption of two incompatible assumptions: first, that Alexandria was an open, tolerant city where different ethnic groups were allowed to flourish and to coexist peacefully; and, secondly, that these ethnic groups were separate from each other, with little or no interaction between them. (Fahmy 2006a, 272)

As a consequence, Fahmy contrasts two different varieties of cosmopolitanism in Alexandria, the "dynamic contiguity" and the "melting pot" one. Such a distinction echoes McPherson's useful differentiation between two meanings of cosmopolitanism, described either as "the presence of a variety of confessional, cultural, and racial groups within a single urban setting" or as the adoption and adaption of "cultural forms drawn from other confessional and national groups" (2002, 83, quoted in Hanley 2008, 1351). From my standpoint, these two cosmopolitanisms do not exclude each other, but they are strictly related: the former can work as a condition of possibility for the latter or they can co-exist in certain moments in specific locations (Gastaut 2002, 1). What in Fahmy's account appears to be an aporia of the Mediterranean cosmopolitan city is, from my standpoint, its secret, deep cipher, its very condition of possibility. It is impossible to draw a clear boundary between the "dynamic contiguity" model and the "melting pot" one, as well as there is not a clear cut between "imperial" and "colonial" cosmopolitanism". The "theoretical" tension between cosmos and polis is hence mirrored in more "empirical" tensions between different cosmopolitanisms in different times and spaces. As a consequence there is not one recipe for cosmopolitanism: we know it is about conviviality, hospitality, and multiple loyalties but the way these are crystallized into a cosmopolitan moment and place cannot be taken for granted. Cosmopolitanism here is not to be interpreted as a status, as a character that one person or community either possesses entirely and integrally or does not at all. It is rather a process, "a mundane administrative practice rather than a sublime ideal" (Hanley 2008, 1360). It works precisely as a "difference machine" à la Isin, as an assemblage of different understandings and practices of loyalty and belonging, making possible to sustain the tension between cosmos and polis. Cosmopolitan identity is always defined "with respect to some far-off reference point, some future, unreachable, historical and geographical horizon, an endlessly deferred, neveraccomplished destiny" (Minca 2009a, 258; see also Mabro 2006, 261).

\section{The Millet as a Cosmopolitan Dispositif}

In this section I argue this point by considering the case for the millet system, viii which "may be defined as a political organization which granted to the non-Muslims the right to organize into communities possessing certain delegated powers, under their own ecclesiastical heads. In time such "communities" or millets developed their own peculiar characteristics and traditions, in this way becoming identified with the 
various nationalities" (Jabber 1967, 212; see also Carleton 1937). The notion of millet is relevant here as it often interpreted as the key dispositif expressing fissiparousness in the Ottoman empire. In reality the millet entailed some civic autonomy for the different non-Muslim communities under the condition that they give up political claim to national sovereignty. Hence, at a first glance the millet system seems to enforce Weber's claims examined in the previous section. My point is that the millet was a far more complex dispositif and should be understood strictly in relation to the governmentality of the tension between cosmos and polis. In particular, it establishes a diachronic continuity between the two moments imperial and colonial - of Mediterranean cosmopolitanism. As Jabber points out the millet was not a creation of Ottoman rulers but it pre-existed their conquest of Constantinople in 1453, it was maintained over the centuries and reformed in the mid-nineteenth century during the Tanzimat period (1967). Furthermore, in Egypt, the millet system survived the British occupation and it was only after the war of 1954 between Israel and Egypt that it was definitively cancelled by Gamal Abdel Nasser (Beinin, 1998, 3644 and 72-76). From this standpoint the millet can be interpreted as a constitutive key element of the Ottoman urban "difference machine". Of course, we should not search in the millet the same features of self-rule and citizenship that emerged in the making of the Westphalian modern state order (Spruyt 2000). We must bear in mind that the millet, as expression of "imperial cosmopolitanism," is rather related to the "dynamic contiguity" model of cosmopolitanism than to the "melting pot" (Fahmy 2006a, 272). At the same time, it can be read as a "condition of possibility" for the emergence of further cosmopolitan moments in the Mediterranean (Driessen 2005, 138). In particular, focusing on the relationship between the millet system and the making and unmaking of colonial cosmopolitanism in Ottoman cities can highlight two key issues in my discussion of Mediterranean cosmopolitanism. The first concerns the way fissiparousness and cosmopolitanism were actually made compatible with each other in order to sustain the tension between the cosmos and the polis. The second relates to the progressive erosion and final destruction of colonial cosmopolitanism in Mediterranean cities.

\section{(Self-)Segregation and Cosmopolitanism}

The viewpoint of colonial cosmopolitanism is often - and rightly - accused of elitism and nostalgia (see, for instance, Hanley 2008), if not explicitly of racism (Fahmy 2006a, 274-276). For instance, in Zubaida's account (2002), Mediterranean cosmopolitanism is seen as the product of an urban elite of Ottoman modernizers, colonial flaneurs, hedonistic libertines, Muslim alcoholics, and heretic frequent travellers, challenging and disaggregating the inherited Oriental fissiparousness. Hence Fahmy is perfectly right to argue for an understanding of the cosmopolitan milieux which takes into account the behaviour of the poorest groups within the city (2006b). In so far as they were in the first instance port cities, Mediterranean cosmopolitan cities hosted not only writers, libertines and bon vivant, but also a variegated population of prostitutes, dockers, gangsters, and adventurers (Cesarani 2002). Consideration of the millet system can thus actually help in reconsidering the elitist and nostalgic dominant narration on colonial cosmopolitanism by taking into account a more nuanced vision of intra-community relations. Millet belonging and loyalty were in fact transversal to class commonality: even when European colonialism and the related diasporas made Mediterranean cosmopolitanism a bourgeois elite's ideal and practice $\grave{a}$ la Durrell, the resilience of the millet system was still tracking links of inter-class solidarity and social mobility (Hanley 2008, 1351), such as in nineteenth and early twentieth century Alexandria (Ilbert 1996) or in Salonika (Mazower 2004). Different generations of immigrants with different social and economic background were overlapping, meeting and interacting in both bourgeois and poorer neighbourhoods. As Julia Clancy-Smith observes in her recent book on European migration in Tunisia (2010), the European diaspora in Mediterranean port 
cities began earlier than the colonial occupation and it was something more than the avant-garde of imminent colonisation, creating the condition for establishing a cosmopolitan milieux. Moreover, as Mabro as argued about Alexandria, diasporic communities were not a monolithic entity but highly differentiated groups, with different aspirations and self-representations (2006, 250-261).

This aspect leads me to consider another key feature of the relationship between self-rule, fissiparousness and cosmopolitanism, that is, spatial self-segregation. Most of the Mediterranean cosmopolitan cities, mainly those whose cosmopolitan history cuts across the two distinct moments of imperial and colonial cosmopolitanism, has been characterized by the spatial juxtaposition of semi-segregated neighbourhood on the base of the ethnic and/or religious affiliation of their inhabitants. This feature does not contradict their supposed cosmopolitanism: cosmopolitanism has not to be interpreted here as a seven-days-a-week and twenty-four-hours-a-day status, but rather a way to secure the governmentality of the "difference machine" and in particular of the tension between cosmos and polis in defining citizenship, belonging and loyalties. Spatial self-segregation was in a sense even reinforced by cosmopolitan practices. On the one hand, as noted above, self-segregation enforced trans-class solidarity: "Jewish dock-workers belong to the same category as Jewish bankers" (Hanley 2008, 1351). On the other hand, in order to sustain the tension between cosmos and polis, such a residential zoning had to be compensated by the existence of other place, such as marketplaces (Matvejevic 1999, 51, 185-191) or cafes (Örs 2002), which actually worked as threshold where the topography of the city made possible to meet and interact with "other" groupings, millet, and citizens was made possible.

Karahasan offers an exemplary description of the dramatic tension between closeness and opening, particular and universal, polis and cosmos which made Sarajevo one of the archetype of cosmopolitanism in the Mediterranean:

The interplay of that which is open and that which is closet, of the external and internal - which mutually comment upon, confront, and reflect each other - is made perfectly clear in the organization of the city. ... The mahalas [ethnic neighbourhoods] are like rays spread around a focal point. ... The center of the city, which is also the geometric center of the space outlined by the mahalas, is Charshiya, where people do not live because it is reserved for workshops, stores and other forms of business. ... This is the foundation of the interplay of opposition and mutual reflection, of openness and closedness, of external and internal that is the most prominent characteristic of Sarajevo. This is also the source of the tension between external and internal, upon which the very foundation of Sarajevo's existence is based. Charshiya is technically closed and semantically open, while each mahala is technically open and semantically closed. Charshiya is universality; mahala is particularity and concreteness. (1994, 8-10)

As Goodwin (2003) stresses such a dramatic tension between the openness of the city center and the jealous closeness of the ethnic neighbourhoods was not exclusive of Sarajevo but was common to all of the Ottoman great cities. In my view, such millet self-segregation should be read as part of the broader dispositif sustaining the tension between cosmos and polis. When this centuries old morphological balance is altered by catastrophic changes in the urban built environment, cosmopolitanism itself is endangered. This was the case in Salonika where a great fire destroyed large parts of the Jewish neighbourhoods in 1917, a few years after it passed from under the Greek rule. The subsequent reconstruction was the occasion to modernize and to Hellenize the morphology of the city itself. As a consequence the Jewish presence spread across eight different and separated neighbourhoods, designed according to class belonging rather than to the former bounded community. This normalization and assimilation of the Jewish population under the twin demands of modernity and capitalism ended up in determining a quick decline, 
both quantitative and qualitative, of both the Jewish community and of the cosmopolitan settings of the city $^{\text {ix }}$ (Hastaoglou-Martinidis 1997).

\section{From Fissiparousness to Urbicide: Unmaking Cosmopolitanism in the Mediterranean}

This relationship between self-rule, fissiparousness, and cosmopolitanism highlights some features of the relationship between cosmopolitanism and nationalism, and contributes to explaining the decline of both imperial and colonial cosmopolitanisms in the Mediterranean (Driessen 2005, 139). The demise of Mediterranean cosmopolitan cities is not simply the uprising of the colonial subalterns, bringing to end imperial and/or colonial domination. Salonica, Trieste, Izmir, Alexandria - and I would add also Jerusalem and Sarajevo - have not been simply liberated from oppressive external rule, but they have been systematically destroyed, in what could be considered a true urbicide (Graham 2004). The reverse also applies: Mediterranean cosmopolitan cities were not an Eden on earth, the embodiment of a perfect communitas imbedded into the wall and the street of an urbs, destroyed by the dark forces of nationalism and parochialism, of ethnic and religious hate. The relationship between cosmopolitanism and urbicide is much more complex and it deserves much more scholarly research than can be offered here. Urban cosmopolitans have been both the victims of fanatical modern nationalisms and the advocates who spread national feelings in imperial and colonial Mediterranean. The making of nation-statehood - what Mignolo refers to as "internal colonialism" (2000b) - was not superimposed to the cosmopolitan milieux but it was worked and reworked from within. In Trieste "cosmopolitan and irredentist ideologies were jointly forged and mutually reinforcing" (Ballinger 2003, 93; see also Minca 2009a). In Istanbul the Young Ottomans' modernization movement was at the same time revitalizing Ottoman cosmopolitanism (Zubaida 2002, 34) and flaming nationalistic feelings among the local intellectuals (Mardin 2000): nationalist Young Ottomans forged cosmopolitanism and cosmopolitan Young Turks realized nationalism (Göçek 1993). Between Salonika and Istanbul, the Dönme (descendants of Sephardic Jews who converted to Islam in the seventeenth century) progressively abandoned their cosmopolitan lifestyle and ideals to embrace Turkish nationalism (Baer 2010). In Aleppo, it was among the Western-educated "reading class" that Turkish nationalism spread and diffused, "cleansing the cosmopolitan city" (Watenpaugh 2005; 2006).

The millet system, while facilitating the emergence of a cosmopolitan milieu had at the same time an ambiguous impact on cosmopolitanism. When the European impact spread over the Mediterranean, modern nationalism found its locus in the long-lasting intertwining of self-rule and fissiparousness (Göçek 1993). Greek nationalism in the Ottoman Empire was enhanced and facilitated by the millet system and by the growing self-rule made available to national groupings and communities in the Tanzimat period (Roudometof 1998; 2010). Challenging the mainstream narrative that sees Zionism as a mainly Ashkenazi project and despite the anti-Zionist feelings of the influential Alliance Israélite Universelle (Rodrigue 2003), nationalism also emerged in the Jewish millet. This was particularly true in the Ottoman Balkans (Benbassa and Rodrigue 2000, 116-157), but also, albeit in a more nuanced manner, in Egypt (Tignor 1980, 445-446; Beinin 1998), while the Jewish millet in Salonika (Mandel 1976, 95) and Istanbul (Stein 2004) maintained a more critical attitude towards Zionism. Moreover, not only nationalism but also capitalism was introduced into the millet system, accelerating the demise of the cosmopolitan experience in the Mediterranean.

According to Robert Tignor, for instance, the shift from a millet-based identity to an haute bourgeoisie class consciousness, although never fully accomplished, contributed to the rise of Greek and Zionist nationalism among the millet elite in Egypt (1980). This tension between cosmos and polis, between universal and particular, embodied in the millet system, became evident in the Tanzimat period when a series of reforms 
aimed to abolish the millet were introduced. These reforms, aimed to facilitate "the transformation of hitherto Muslim, Christian and Jewish subjects into Ottomans" (Hanioǵlu 2008, 74; see also Barkey 2008) and to establish "a common Ottoman citizenship" (208), met the resistance not only of Muslim religious authorities but also of the millet representatives (75-76). Once again, cosmopolitan Mediterranean cities were facing an aporia. On the one hand, by accepting Western universalism and secular political, social and cultural customs, Tanzimat modernisation, was setting the conditions for colonial cosmopolitanism to emerge. On the other hand, in order to counter-act the growing nationalist feeling among the ethnic and religious minorities and to encourage Ottoman belonging and loyalty, it undermined the millet dispositif which worked as a condition of possibility for cosmopolitanism itself. As Malte Fuhrmann claims,

The dividing line between social practices inspired by nationalism and those inspired by cosmopolitanism does not reveal two neatly separated camps. Instead, the actions of individuals often followed both of these seemingly contradictory modes of social intercourse. Decisions on which of these modes should be followed were often made on a day to day basis. $(2003,46-47)$

As a consequence, the relationship between fissiparousness, self-rule, and cosmopolitanism in the millet dispositif is much more complex as I envisage it than in Weber's and Zubaida's accounts. Colonial cosmopolitanism emerged from the encounter of the Ottoman imperial cosmopolitanism, immanent in the millet system, with the European impact. It was therefore overlapping and the blurring of what Waley calls Oriental and European cosmopolitanism (2009). This encounter produced the condition of possibility for Mediterranean cosmopolitanism, but also for its demise and for subsequent urbicide. From this standpoint, 'colonial cosmopolitanism' should be read as something more complex than an elitist project, nowadays read through the lenses of memory and nostalgia. The question now remains as to what might be learned from the Mediterranean experience of cosmopolitanism.

\section{Anything Left? Anything to be Learned?}

Through the spatial oxymoron inherent to it, the concept of cosmopolitanism establishes a tension between the cosmos and the polis. Thinking in-between these dichotomies entails a critical and radical rethinking of both the conceptions of cosmopolitanisms and the spatial categories adopted to make sense of them. Cosmopolitanism is neither simply about "the concern for the world as it were one polis" (Benhabib, 2004: 174) nor simply about being a citizen of the world, and neither can its spatiality be reduced to a global sense of place à la Massey (1994, 146-156). Cosmopolitanism is rather a matter of being in-between the cosmos and the polis, dwelling in a field of tensions where both are simultaneously present, enabling each other but continuously negotiating each other borders. Cosmopolitanism has to be read here as specific spatio-temporal dispositif securing the governmentality of the city as a "difference machine" and the co-existence of multiple and complex accounts of citizenship. The crucial point here is that this is not a mere substitution: cosmo-imperial citizenship replacing poli-urban citizenship. Cosmopolitanism is not even about another kind of citizenship, a cosmopolitan one, like in much of the contemporary literature (Linklater 2007; Delanty 2009). Cosmopolitanism is about sustaining a dramatic tension between these two sources (cosmos and polis, imperial and urban) of citizenship rather than deciding about which one prevails over the other. In Trieste as in many other Mediterranean cosmopolitan cities, cosmopolitanism is about reconciling the ir-reconcilable (Bazlen 1984, 251, quoted in Bialasiewicz and Minca 2010, 1089). A third is not given: cosmopolitanism is not a space outside this tension, but it is the in-between of such a tension. This tension simultaneously sustains and undermines cosmopolitanism, which at any point can turn into vernacularism and nationalism and even lead to the extreme outcome of 
urbicide. Just as in Karahasan's account of Sarajevo's siege, the stones, the houses, the walls, the streets themselves of the cosmopolis can both evoke conviviality and encounter and provoke rage and violence. So what can be learned from such a precarious cosmopolitanism? It is certain that it cannot supply us with a normative and universal agenda for governing contemporary cosmopolitanization. It cannot offer the European Union's techno-bureaucracy a cosmopolitan model to address its citizenship dilemmas like many 'new cosmopolitans' would like (Benhabib 2006; Beck and Grande 2007; Rumford 2007). It plays neither the trumpet of human rights nor the drums of humanitarian war. Rather the ambiguous variations of the Arab music that cosmopolitan Bela Bartok defended against Ottoman modernists at the 1932 Congress of Arab Music in Cairo (Zubaida 2002, 38). In Chambers' words, "it is full of discontinuous histories, the sounds of the voices that evade conclusions, accents that to not seek to domesticate the world but, rather, bear interrogations that promote a sense of the unhomely, full of memories that ... draw blood" $(2008,55)$.

Despite the impotence of Mediterranean cosmopolitanisms in providing a universal, "positive," normative synthesis, cosmopolitanism is back again in the Mediterranean. It sustains both neo-liberal projects for urban regeneration, such as in Trieste (Colombino 2009), Alexandria (Della Dora 2006), and Istanbul (Mills 2010) and the building of national identity in places such as Israel, where the "melting pot" ideal goes hand in hand with the (ab)use of Ottoman legislation to seize land and evict Arab farmers. At the same time, neoOttomanism nostalgia has emerged in the Mediterranean, for example in Turkey where understanding Ottoman citizenship is a key moment in further elaborating its position in a globalized world (Isin 2005; 2010). Finally, while I am writing these conclusive remarks, the Southern shores of the Mediterranean are flamed by the popular quest for change and democratization: soon 'new cosmopolitans' (Nobel Prize winners, famous scientists, intelligence service chiefs, international civil servants) will have to negotiate power with Islamist activists and their alternative universalism of the Umma. In all these cases some lesson must be learned from the historical experiences of imperial and colonial cosmopolitanisms, from these fragile attempts to sustain the tension between the cosmos and the polis.

\section{References Cited}

Abu-Lughod, J. 1991. Before European Hegemony. Oxford: Oxford University Press.

Appiah, K. 2006. Cosmopolitanism. New York: W.W. Norton.

Archibugi, D. 2004. Cosmopolitan Democracy and its Critics: A Review. European Journal of International Relations 10 (3): 437-473.

Barkey, K. 2008. Empire of Differences. The Ottomans in Comparative Perspective. Cambridge: Cambridge University Press.

Beck U. 2002. Cosmopolitanism and its Enemies. Theory, Culture and Society 19 (1-2): 17-44.

Beck, U. 2006. Cosmopolitan Vision. Cambridge: Polity Press.

Beck, U. and E. Grande. 2006. Cosmopolitan Europe. London: Polity Press.

Beck U. and N. Sznaider. 2006. The Literature on Cosmopolitanism: An Overview. British Journal of Sociology 57 (1): 153-164.

Beinin, J. 1998. The Dispersion of Egyptian Jewry. Berkeley: University of California Press. 
Ben Naeh, Y. 2008. Jews in the Realm of the Sultans. Jerusalem: Magnes Press.

Benbassa, E. and A. Rodriguez. 2000. Sephardi Jews. Berkeley: University of California Press.

Benhabib, S. 2006. Another Cosmopolitanism. Oxford: Oxford University Press.

Benton, L.A. 2010. A Search for Sovereignty. Law and Geography in European Empires, 1400-1900.

Cambridge: Cambridge University Press.

Bernasconi, R. 2001. Who Invented the Concept of Race? Kant's Role in the Enlightenment Construction of Race. In Race, edited by S. Bernasconi. London, Blackwell.

Bialasiewicz, L. and C. Minca. 2009. The 'Border Within': Inhabiting the Border in Trieste. Environment and Planning D 28: 1084-1105.

Binnie, J. 2006. Cosmopolitan Urbanism. London: Routledge.

Bourguet M-N., B. Lepetit, D. Nordman, and M. Sinarellis. 1998. L'invention Scientifique de la Méditerranée. Paris: EEHESS.

Braudel, F. 1972. The Mediterranean and the Mediterranean World in the Age of Philip II. London: Collins.

Calhoun, C. 2002. The Class Consciousness of Frequent Travellers. South Atlantic Quarterly 101 (4): 869897.

Calhoun, C. 2008. Cosmopolitanism in the Modern Social Imaginary. Dædalus 137 (3): 105-114.

Cesarani, D. 2002. Port Jews. London: Routledge.

Chambers, I. 2008. Mediterranean Crossings. Durham: Duke University Press.

Cheah, P. 2006. Inhuman Conditions. Cambridge, Mass.: Harvard University Press.

Colombino, A. 2009. Multiculturalism and Time in Trieste: Place-marketing Images and Residents'

Perceptions of a Multicultural City. Social and Cultural Geography 10 (3): 279-297.

Cosgrove, D. 2003. Globalism and Tolerance in Early Modern Geography. Annals of the Association of American Geographers 93 (4): 852-870.

Cresswell, T. 2004. Place: A Short Introduction. London: Blackwell.

Delanty, G. 2006. The Cosmopolitan Imagination: Critical Cosmopolitanism and Social Theory. British Journal of Sociology 57 (1): 25-47.

Delanty, G. 2009. The Cosmopolitan Imagination. Cambridge: Cambridge University Press.

Della Dora, V. 2006. The Rhetoric of Nostalgia: Postcolonial Alexandria between Uncanny Memories and Global Geographies. Cultural Geographies 13 (2): 207-238.

Donia, R.J. 2006. Sarajevo: A Biography. London: Hurst \& Co.

Driessen, H. 2005. Mediterranean Port Cities: Cosmopolitanism Reconsidered. History and Anthropology 16 (1): 129-141. 
Escallier, R. 2003. Le Cosmopolitisme Méditerranéen : Réflexions et Interrogations. Cahiers de la Méditerranée [En ligne] 67, Consulté le 26 janvier 2011. [http://cdlm.revues.org/index120.html]

Eldem E., D. Goffman, and B. Masters. 1999. The Ottoman City between East and West. Cambridge: Cambridge University Press.

Fahmy, K. 2006a. For Cavafy, with Love and Squalor. Some Critical Notes on the History and Historiography of Modern Alexandria. In Alexandria. Real and Imagined, edited by A. Hirst and M. Silk, 263-280. Cairo: American University of Cairo Press.

Fahmy, K. 2006b. Towards a Social History of Modern Alexandria. In Alexandria. Real and Imagined, edited by A. Hirst and M. Silk, 281-306. Cairo: American University of Cairo Press.

Fuhrmann, M. 2003. Cosmopolitan imperialists and the Ottoman Port Cities. Conflicting Logics. In the Urban Social Fabric. Cahiers de la Méditerranée [En ligne], 67, Consulté le 26 janvier 2011, http://cdlm.revues.org/index128.html

Gastaut, Y. 2002. Le Cosmopolitisme, un Univers de Situations. Cahiers de l'Urmis [En ligne], 8, Consulté le 26 janvier 2011, http://urmis.revues.org/index21.html

Giaccaria, P. and C. Minca. 2011. The Mediterranean Alternative. Progress in Human Geography 35 (3): $345-$ 365.

Gidwani, V. 2006. Subaltern Cosmopolitanism as Politics. Antipode 38 (1): 1-17.

Goodwin, J. 2003. Lords of the Horizons: A History of the Ottoman Empire. London: Picador.

Graham, S. 2004. Cities, War and Terrorism. Towards an Urban Geopolitics. Oxford: Blackwell.

Guthenke, C. 2008. Placing Modern Greece. Oxford: Oxford University Press.

Hanioǵlu, M. 2008. A Brief History of the Late Ottoman Empire. Princeton: Princeton University Press.

Hanley, W. 2008. Grieving Cosmopolitanism in Middle East Studies. History Compass 6 (5): 1346-1367.

Harvey, D. 2000. Cosmopolitanism and the Banality of Geographical Evils. Public Culture 12 (2): 529-564.

Harvey, D. 2009. Cosmopolitanism and the Geographies of Freedom. New York: Columbia University Press.

Hedrick, T. 2008. Race, Difference, and Anthropology in Kant's Cosmopolitanism. Journal of the History of Philosophy 46 (2): 245-268.

Held D. 2010. Cosmopolitanism: Ideals and Realities. Cambridge: Polity Press.

Herzfeld, M. 1984. The Horns of the Mediterraneanist Dilemma. American Ethnologist 11 (3): 439-454.

Herzfeld, M. 2005. Practical Mediterraneanism. Excuses for Everything, from Epistemology to Eating. In Rethinking the Mediterranean, edited by W. Harris, 45-63. Oxford: Oxford University Press.

Hirst, A. and M. Silk, eds. 2006. Alexandria. Real and Imagined. Cairo: American University of Cairo Press. Horden P. and N. Purcell. 2000. The Corrupting Sea. A Study of Mediterranean History. Oxford: Blackwell. 
Karahasan, D. 1994. Sarajevo, Exodus of a City. New York: Kodansha America.

Kramsch, O. 2007. Querying Cosmopolis at the Borders of Europe. Environmental and Planning A 39 (7): $1582-1600$.

Ilbert, R. 1996. Alexandrie, 1830-1930. Cairo: IFAO.

Isin E. 2002. Being Political: Genealogies of Citizenship. Minneapolis: University of Minneapolis Press.

Isin, E. 2005. Citizenship after Orientalism: Ottoman Citizenship. In Challenges to Citizenship in a Globalizing World, edited by F. Keyman and A, Icduyg, 31-51. London: Routledge.

Isin, E. 2010. The Soul of a City: Hüzün, Keyif, Longing. In Orienting Istanbul: Cultural Capital of Europe? edited byD. Göktürk, L. Soysal, and I. Türeli, 35-47. London: Routledge.

Latham, A. 2002. Re-theorizing the Scale of Globalization: Topologies, Actor-networks and

Cosmopolitanism. In Geographies of Power, edited by A. Herod and M. Wright, 115-143. London: Blackwell.

Leontidou, L. 2010. Urban Social Movements in 'Weak' Civil Societies: The Right to the City and Cosmopolitan Activism in Southern Europe. Urban Studies 47 (10): 1179-1203.

Levy, A. 2002. Jews, Turks, Ottomans. Syracuse: Syracuse University Press.

Lilley, K. 2004. Mapping Cosmopolis: Moral Topographies of the Medieval City. Environment and Planning D 22: 681-698.

Linklater A. 2007. Critical Theory and World Politics: Citizenship, Sovereignty and Humanity. London: Routledge.

Mabro, R. 2006. Alexandria 1860-1960. The Cosmopolitan Identity. In Alexandria, Real and Imagined, edited by A. Hirst and M. Silk, 247-262. Cairo: American University of Cairo Press.

Massey, D. 1994. Space, Place and Gender. Minneapolis: University of Minnesota Press

Matvejevic, P. 1999. Mediterranean. A Cultural Landscape. Berkeley: University of California Press.

Mawson, W. 1921. The Salonika Town Planning Act Illustrated. Town Planning Review 9 (3): 147-154.

Mazower, M. 2004. Salonica. City of Ghosts. New York: Alfred A. Knopf.

Mignolo W. 2000a. The Many Faces of Cosmo-polis: Border Thinking and Critical Cosmopolitanism. Public Culture 12 (3): 721-748

Mignolo W. 2000b. Local Histories/Global Designs: Coloniality, Subaltern Knowledges and Border Thinking. Princeton: Princeton University Press.

Mignolo, W. 2010. Cosmopolitanism and the De-colonial Option. Studies in Philosophy and Education 29 (2): 111-127.

Miller, W. 1966. The Ottoman Empire and its Successors, 1801-1927. London: Routledge.

Mills A. 2010. Streets of Memory: Landscape, Tolerance, and National Identity in Istanbul. Athens, Ga.: University of Georgia Press. 
Minca, C. 2009a. 'Trieste Nazione' and its Geographies of Absence. Social and Cultural Geography 10 (3): 257-277.

Minca, C. 2009b. Speaking Triestino: Language, Practice and Social Capital in Trieste. In Social Capital and Urban Networks of Trust, edited by J. Hakli, and C. Minca, 173-203. Aldershot: Ashgate.

Moore, B. 2001. Ethnic and Religious Hostilities in Early Modern Port Cities. International Journal of Politics, Culture, and Society 4 (4): 687-727.

Nussbaum, M. 1994. Patriotism and Cosmopolitanism. Boston Review 195: 3-34.

Nussbaum, M. 1997. Kant and Stoic Cosmopolitanism. Journal of Political Philosophy 5 (1): 1-25.

Pagden, A. 2000. Stoicism, Cosmopolitanism and the Legacy of European Imperialism. Constellations 7 (1): 3-22.

Parekh, B. 2006. Rethinking Multiculturalism. Basingstoke: Palgrave Macmillan.

Pieterse, J. 2006. Emancipatory Cosmopolitanism: Towards an Agenda. Development and Change 37 (6): $1247-1257$.

Pollock, S. 2000. Cosmopolitan and Vernacular in History. Public Culture 12 (3): 591-625.

Pollock, S., H. Babha, C. Breckinridge, and D. Chakrabarty. 2000. Cosmopolitanisms. Public Culture 12 (3): 577-589.

Popke, J. 2007. Geography and Ethics: Spaces of Cosmopolitan Responsibility. Progress in Human Geography 31 (4): 509-518.

Purvis, M. 2009. Between Late-lasting Empire and Late-developing Nation-state. A Triestine Perspective on City-state Relations. Social and Cultural Geography 10 (3): 299-317.

Rundell, J. 2004. Strangers, Citizens and Outsiders: Otherness, Multiculturalism and the Cosmopolitan Imaginary in Mobile Societies. Thesis Eleven 78 (1): 85-101

Rumford C. 2007. Cosmopolitanism and Europe. Liverpool: Liverpool University Press.

Saïd, S 2005. The Mirage of Greek Continuity. In Rethinking the Mediterranean, edited by W. Harris, 268293. Oxford: Oxford University Press.

Schueth, S. and J. O'Loughlin. 2008. Belonging to the World: Cosmopolitanism in Geographic Contexts. Geoforum 39 (2): 926-941.

Söderström, O. 2006. Studying Cosmopolitan Landscapes. Progress in Human Geography 30 (5): 553-558.

Söderström, O. 2009. Urban Cosmographies. Indagine sul Cambiamento Urbano a Palermo. Rome:

Meltemi.

Solnon, J. 2009. Le Turban et la Stambouline. Paris: Perrin.

Spruyt, H. 2000. The End of Empire and the Extension of the Westphalian System. International Studies Review 2 (2): 65-92. 
Stein, S. 2000. Creating a Taste for News: Historicizing Judeo-Spanish Periodicals of the Ottoman Empire. Jewish History 14 (1): 9-28.

Taylor, P. 1999. The United Nations in the 1990s: Proactive Cosmopolitanism and the Issue of Sovereignty. Political Studies 47 (3): 538-565.

Tignor, R. 1980. The Economic Activities of Foreigners in Egypt, 1920-1950: From Millet to Haute Bourgeoisie. Comparative Studies in Society and History 22 (3): 416-449.

Toulmin, S. 1992. Cosmopolis. The Hidden Agenda of Modernity. Chicago: Chicago University Press.

Vertovec S. and R. Cohen. 2003. Conceiving Cosmopolitanism. Oxford: Oxford University Press.

Waley, P. 2009. Introducing Trieste: A Cosmopolitan City? Social and Cultural Geography 10 (3): 243-256.

Werbner, P. 1999. Global Pathways: Working Class Cosmopolitans and the Creation of Transnational Ethnic Worlds. Social Anthropology 7 (1): 17-35.

Yovel, Y. 2009. The Other Within. The Marranos. Princeton: Princeton University Press.

Zilfi, M. 2010. Women and Slavery in the Late Ottoman Empire. Cambridge: Cambridge University Press. Zubaida, S. 2002. Middle Eastern Experiences of Cosmopolitanism. In Conceiving Cosmopolitanism, edited by S. Vertovec and R. Cohen, 32-41. New York: Oxford University Press.

\footnotetext{
i Of course this is not the context in which to discuss the genealogy of the "place versus space" debate in contemporary Anglo-American geography. To the extent that such a controversy is relevant for our understanding of the cosmopolitanism debate see, among others, Cresswell (2004), in particular chapter 3 comparing Harvey's and Massey's understanding of place/space.

ii For an thorough account of the relationship between Kant's racist anthropology and geography and his account of cosmopolitanism, see Bernasconi (2001), Hedrick (2008) and Harvey (2000; 2009).
}

\footnotetext{
iii On the peculiarity of the Judeo-Spanish culture in the Balkans see Benbassa and Rodriguez (2000).

iv See, among other, classic Miller's The Ottoman Empire and its Successors (1966).
} 
${ }^{v}$ On the importance of pre-modern cosmographies in shaping an alternative understanding of cosmopolitanism, see Cosgrove (2003) and Lilley (2004). See also, for a more normative account of the relationship between cosmographies and cosmopolitanism, Bartelsons (2009).

vi Interestingly the Italian philosopher Massimo Cacciari establishes a comparison between the metic condition in the Greek polis and the dhimmī status of Greeks and Jews under Ottoman rule $(2004,11)$.

vii Empires themselves should not be interpreted as homogenous, consistent, smooth territories but rather as contradictory, striated spaces, where different orders and architectures coexisted (see, for instance, Benton 2010).

viii Of course, this is the place neither to discuss the complexity and the ambiguity of a notion such as that of millet. See, among other, Kymlicka (1992), Isin $(2005,44)$ and Rowe (2007).

ix It is worth noticing that also in Smyrna/Izmir a fire, set by Turkish nationalist in 1922, marked the end of the cosmopolitan aura of the city according to Eldem (Eldem et al. 1999, 132-133). 